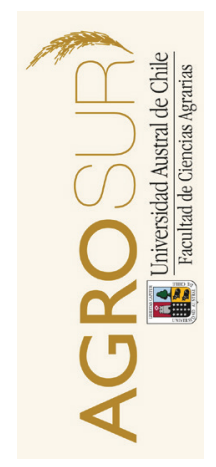

\title{
Contribución de la pradera al desarrollo de sistemas productivos sustentables
}

\section{Contribution of grasslands to the development of sustainable production systems}

\author{
Acuña, H. ${ }^{a}$, Alonso, M. ${ }^{b}$, Ayala, W. ${ }^{c}$, Balocchi, 0. ${ }^{b}$, Dorner, J. ${ }^{d, e}$, Flores, P. \\ Hernández-Garay, A. ${ }^{g}$, Keim, J.P. ${ }^{b}$, Kemp, P.H, Laca, E. ${ }^{i}$, López, I. ${ }^{h}$ \\ a Facultad de Agronomía, Universidad de Concepción, Chillán, Chile \\ b Instituto de Producción Animal, Universidad Austral de Chile, Valdivia, Chile. \\ ${ }^{c}$ Instituto Nacional de Investigación Agropecuaria, Treinta y Tres, Uruguay \\ d Instituto de Ingeniería Agraria y Suelos, Universidad Austral de Chile, Valdivia, Chile. \\ e Centro de Investigación en Suelos Volcánicos, Universidad Austral de Chile, Valdivia, Chile. \\ ${ }^{\mathrm{f}}$ Escuela de Graduados, Facultad de Ciencias Agrarias, Universidad Austral de Chile, Valdivia, Chile. \\ ${ }^{g}$ Colegio de Postgraduados, Campus Montecillo, Montecillo, Texcoco, Mexico \\ ${ }^{\mathrm{h}}$ Institute of Agriculture and Environment, Massey University, Palmerstone North, New Zealand. \\ ${ }^{i}$ Department of Plant Sciences, University of California, Davis, California, USA.
}

\section{E D I T O R I A L}

Grasslands constitute one of the largest biomes of the planet, with an extension of 46 million $\mathrm{km}^{2}$, which represents $26 \%$ of the land and $80 \%$ of the agricultural land of the world. They are present in every continent, excluding Antarctica, and distributed in a wide range of edaphic and climatic conditions, from those too wet to be deserts to those too dry to sustain forests.

The evolution of humans has been tightly linked to the emergence of grasslands. Since the appearance of the first hominids, grasslands were the main scenario for their evolution, promoting the development of the traits that make us humans. At the beginning they were a place for hunting and gathering, as well as for the domestication of wild animals and a primitive agriculture. Nowadays, grasslands are the basis for highly developed global industries, such as the meat, milk and wool industries. Moreover, $68 \%$ of the grasslands are in developing countries, where they play a central role in the life of millions of farmers.

Grasslands are areas dominated by herbaceous vegetation that can be consumed directly by herbivores or harvested for fresh or conserved forage. The floristic composition of grasslands varies, including grasses, legumes, other forbs and shrub and tree species. Thus, there is a wide variety of grasslands, from natural grasslands to short rotation seeded pastures. Despite the differences between them, they all share the same role as the basis of grazing systems, especially with ruminants. In this context, grasslands serve as the link between soils and animals, generating foods of high nutritional value for humans. The high demand for animal products, which is expected to reach a $25 \%$ increase by 2030, will require greater efficiency and sustainability of grazing systems to satisfy the needs of the present generation without sacrificing the potential to provide for future generations.

Although the main role of grasslands at the present is to support domestic animals, grasslands also sustain wild ecosystems and offer multiple goods and services, such as biodiversity conservation, recovery of degraded soils, water harvest and $\mathrm{CO}_{2}$ sequestration. All aspects of grasslands have been the object of extensive scientific research, originating different fields of work. In this special issue of the Agro Sur journal titled "Contribution of grasslands to the development of sustainable production systems", we present advances in some of these fields. Thus, this issue includes articles about grasslands with a wide geographical distribution, from California in the USA, to New Zealand and the Chilean Patagonia. Articles introduce results of a wide range of topics, from ordination and classification of rangelands to response of grasslands productivity to different conditions of soil fertility, irrigation, management and stress. The collection includes articles on defoliation, selectivity, intake and seed recruitment, and on the effect of grasslands on soil physical properties. We trust that these articles will contribute to the advancement of knowledge on the structure, function and management of grasslands worldwide. 


\section{EDITORIAL}

Las praderas constituyen uno de los mayores biomas del planeta con una superficie de 46 millones de $\mathrm{km}^{2}$, lo que corresponde a un $26 \%$ de la superficie terrestre y un $80 \%$ de la superficie agrícola del mundo. Ellas están presentes en todos los continentes, salvo en el continente antártico, distribuyéndose en una amplia gama de condiciones edafoclimáticas, desde muy húmedas para ser desiertos a muy secas para sostener bosques.

La evolución del ser humano está estrechamente ligada al surgimiento de las praderas. Desde la aparición de los primeros homínidos, las praderas constituyeron el principal escenario para su evolución, motivando el desarrollo de las características que nos hacen humanos. En un principio fueron lugar para actividades de caza y recolección, así como para la domesticación de animales silvestres y ganadería primitiva. En la actualidad, las praderas son la base de industrias globales de gran desarrollo, como las industrias de la carne, leche y lana. Además, un 68\% de la superficie de praderas se encuentra en países en desarrollo, donde cumplen un rol central en la calidad de vida de millones de productores agrícolas.

Conceptualmente, las praderas son territorios dominados por vegetación herbácea, la cual puede ser consumida directamente por animales o cosechada para forraje verde o conservado. La composición florística de las praderas es variada, e incluye gramíneas, leguminosas, otras hierbas y especies arbóreas y arbustivas. Es así como se puede encontrar una amplia gama de praderas, desde las naturales hasta las sembradas de rotación corta. A pesar de las diferencias entre ellas, todas cumplen un rol común: Servir de base para los sistemas pastoriles, especialmente de rumiantes. En este contexto, la pradera actúa como nexo entre el suelo y el animal, generando alimentos de elevado valor nutricional para el ser humano. La creciente demanda por productos de origen animal, que se espera alcance un aumento del 25\% hacia el 2030, obliga a los sistemas pastoriles a aumentar su eficiencia y sustentabilidad, para satisfacer las necesidades de la generación actual sin sacrificar la capacidad de proveer a las generaciones futuras.

A pesar que en la actualidad el principal uso de las praderas es la producción de ganado doméstico, ellas también son la base de ecosistemas de vida silvestre y proveen múltiples bienes y servicios, como la conservación de la biodiversidad, la recuperación de suelos degradados, la cosecha de agua y la captura de $\mathrm{CO}_{2}$, por mencionar sólo algunos. Dichos aspectos han sido objeto de una extensa investigación científica, dando origen a diferentes líneas de trabajo. En el presente número especial de praderas de la revista Agro Sur titulado "Contribución de la pradera al desarrollo de sistemas productivos sustentables", hemos querido dar cuenta de los avances en muchas de ellas. Así, este número incluye artículos sobre praderas en una amplia distribución geográfica, desde California, en los Estados Unidos, hasta Nueva Zelandia y la Patagonia chilena. Los artículos presentan resultados de trabajos en una también amplia gama de temas, los que incluyen el ordenamiento y clasificación de pastizales, la respuesta productiva de praderas a diferentes condiciones de fertilidad de suelos, riego, manejo y fuentes de estrés. También incluye estudios de defoliación, selectividad, consumo y reclutamiento de semillas, así como sobre el efecto de las praderas en las propiedades físicas del suelo. Estamos seguros que los trabajos presentados en este número especial contribuirán al avance del conocimiento sobre la estructura, funcionamiento y manejo de las praderas en diferentes partes del mundo. 